\title{
The Einstein-Brazil Fogarty: A decade of synergy
}

\author{
Joshua D. Nosanchuk ${ }^{1}$, Murphy D. Nosanchuk ${ }^{1,2}$, Marcio L. Rodrigues ${ }^{2,3}$, \\ Leonardo Nimrichter ${ }^{2}$, Antonio C. Campos de Carvalho ${ }^{4}$, Louis M. Weiss ${ }^{5}$, \\ David C. Spray ${ }^{6}$, Herbert B. Tanowitz ${ }^{5}$ \\ ${ }^{1}$ Departments of Medicine, Microbiology \& Immunology, Albert Einstein College of Medicine, \\ Bronx, NY, EUA. \\ ${ }^{2}$ Instituto de Microbiologia Professor Paulo de Góes, Universidade Federal do Rio de Janeiro, \\ Rio de Janeiro, RJ, Brazil. \\ ${ }^{3}$ Centro de Desenvolvimento Tecnológico em Saúde, Fundação Oswaldo Cruz, Rio de Janeiro, RJ, Brazil. \\ ${ }^{4}$ Instituto de Biofísica, Universidade Federal do Rio de Janeiro, Rio de Janeiro, RJ, Brazil. \\ ${ }^{5}$ Departments of Pathology and Medicine, Albert Einstein College of Medicine, Bronx, NY, EUA. \\ ${ }^{6}$ Departments of Neuroscience and Medicine, Albert Einstein College of Medicine, Bronx, NY, EUA.
}

Submitted: November 24, 2014; Approved: March 5, 2015.

\begin{abstract}
A rich, collaborative program funded by the US NIH Fogarty program in 2004 has provided for a decade of remarkable opportunities for scientific advancement through the training of Brazilian undergraduate, graduate and postdoctoral students from the Federal University and Oswaldo Cruz Foundation systems at Albert Einstein College of Medicine. The focus of the program has been on the development of trainees in the broad field of Infectious Diseases, with a particular focus on diseases of importance to the Brazilian population. Talented trainees from various regions in Brazil came to Einstein to learn techniques and study fungal, parasitic and bacterial pathogens. In total, 43 trainees enthusiastically participated in the program. In addition to laboratory work, these students took a variety of courses at Einstein, presented their results at local, national and international meetings, and productively published their findings. This program has led to a remarkable synergy of scientific discovery for the participants during a time of rapid acceleration of the scientific growth in Brazil. This collaboration between Brazilian and US scientists has benefitted both countries and serves as a model for future training programs between these countries.
\end{abstract}

Key words: international collaboration, training grant, microbial pathogenesis, global health.

\section{Introduction}

In 2004, a United States of America National Institutes of Health Fogarty International Center Research Training Grant was awarded to Global Health research scientists at the Albert Einstein College of Medicine (Einstein), Bronx, NY, USA in collaboration with investigators within the Federal University (in Rio de Janeiro, Minas Gerais and Sao Paulo) and the Oswaldo Cruz Foundation (Fiocruz; in Rio de Janeiro, Bahia and Curitiba) systems in Brazil. To date, the Fogarty has supported young Brazilian scientists for both short term (months) to year-long re- search experiences in laboratories at Einstein. These researchers would engage mentors at Einstein as well as their mentors in Brazil, complete formal coursework, and present their findings in an ongoing manner, both at Einstein and at national and international meetings (Figure 1). Remarkably, 43 Brazilian trainees have been funded by the Einstein Fogarty. At the outset of the grant, a deep strength of the Fogarty was the fact that there were long-standing collaborations already in place between several of the US principal scientists and their Brazilian counterparts, and these interactions have only grown over the course of this program. It is notable that Albert Einstein himself was in- 


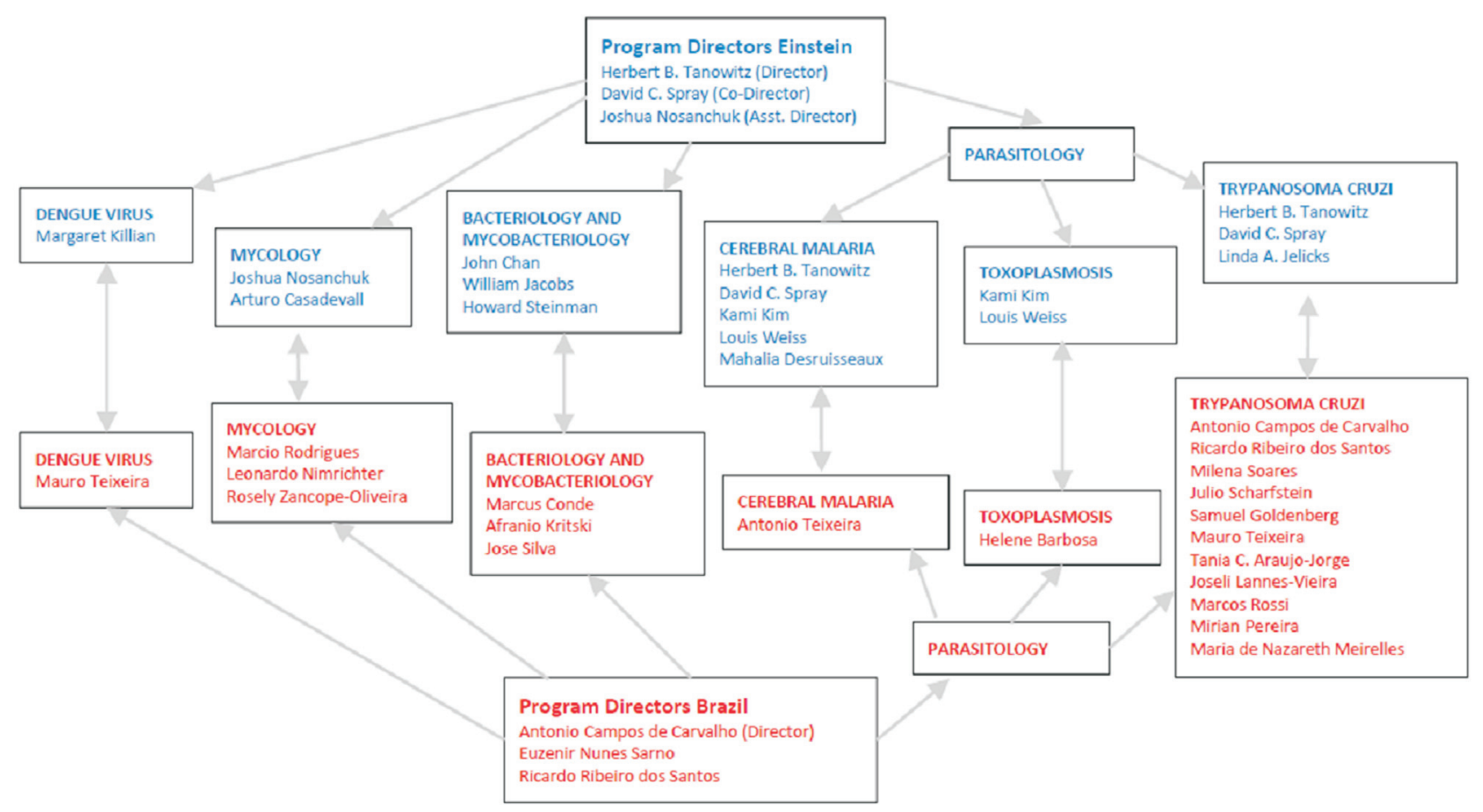

Figure 1 - The structure of the Einstein-Brazil Fogarty program. The diagram shows the ongoing collaborative interactions of scientists from both Einstein faculty (in blue) and the laboratory leaders in Brazil (in red).

terested and excited by the rich research being performed in Brazil and that the work accomplished over the course of this Fogarty is an homage to the desires of both Einstein and Carlos Chagas to improve the lives of all the world's citizens through collaborative discoveries (Figure 2). In the summer of 2015, the Einstein Fogarty ended as Brazil's international position moves the collaboration outside of the scope of the NIH program. However, given all of the scientific accomplishments by the Fogarty trainees, this article was written to underscore the successes supported through this wonderful collaboration, to serve as a roadmap for future international efforts to foster the growth of scientific endeavors throughout the world, and to call attention for the need for ongoing support of global research collaborations. We enthusiastically acknowledge that the Brazilian Scientific Mobility Program (Science without Borders), sponsored by Coordenação de Aperfeiçoamento de Pessoal de Nível Superior (CAPES) and Conselho Nacional de Desenvolvimento Científico e Tecnológico $(\mathrm{CNPq})$ is a major success in providing future students to continue along research pathways along the lines of those achieved with the Einstein Fogarty.

The premise of the Einstein Fogarty was that it was important to work to enhance the capabilities of Brazilian scientists to combat the intractable infectious diseases endemic in Brazil. The diseases selected were therefore conditions of high priority in Brazil for which there existed expertise in a strong laboratory within Einstein; the diseases included fungal diseases (i.e., histoplasmosis, sporotri- chosis), parasitic diseases (Chagas disease, toxoplasmosis and malaria) and bacterial diseases (legionnaires disease and tuberculosis). The research that the Brazilian trainees performed while at Einstein was individually designed to maximize each student's focused learning to areas of research both technical and supportive that are not readily available in Brazil. Moreover, the training program also was designed to include both didactic and laboratory components, as well as formal courses in ethics and the responsible conduct of research. The overall Fogarty program at Einstein has been under the direction of Herbert Tanowitz, $\mathrm{MD}$ with the dedicated assistance of David Spray, $\mathrm{PhD}$ as the co-director and Joshua Nosanchuk, MD as the assistant program director as well as with the enthusiastic support of a strong cohort of Einstein mentors (Figure 3). Dr. Antonio Carlos Campos de Carvalho, professor at Federal University of Rio de Janeiro (UFRJ) has served as the Brazilian Director along with the Brazilian co-principal investigators Drs. Euzenir Nunes Sarno, Fiocruz, Rio de Janeiro, and Ricardo Ribeiro dos Santos, Fiocruz, Salvador.

\section{Formal Courses Provided to Brazilian Trainees}

The Brazilian students spending a year at Einstein undertook training in the responsible conduct of research. A longstanding strength of Einstein is its high quality teaching in research ethics, led by Dr. Ruth Macklin. The topics covered in the research ethics course include: risk-benefit assessments; informed consent; privacy and confidentiality of research subjects and data; ethical issues in epidemiolog- 


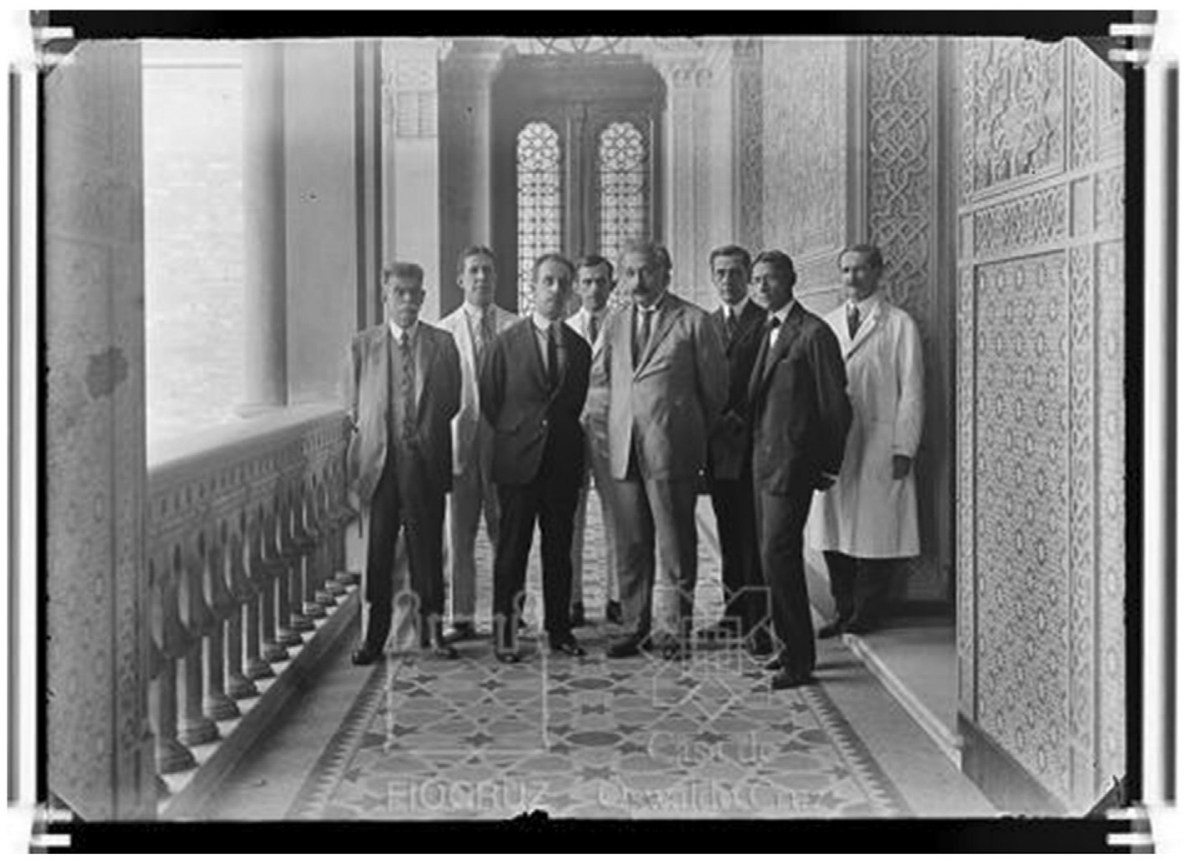

Figure 2 - Photograph title: Carlos Chagas (Receives Albert Einstein at Oswaldo Cruz Institute) recebe a visita de Albert Einstein no Instituto Oswaldo Cruz, em maio de 1925. Catalog number: BR RJCOC 02-10-20-20-006-V03-009 (http://arch.coc.fiocruz.br/index.php/carlos-chagas-recebe-visita-de-albert-einstein-no-instituto-oswaldo-cruz-em-maio-de-1925-na-fotografia-carlos-burle-de-figueiredo-antonioeugenio-de-area-leao-nicanor-botafogo-goncalves-da-silva-adolpho-lutz-alcides-godoy-carlos-chagas;isad)

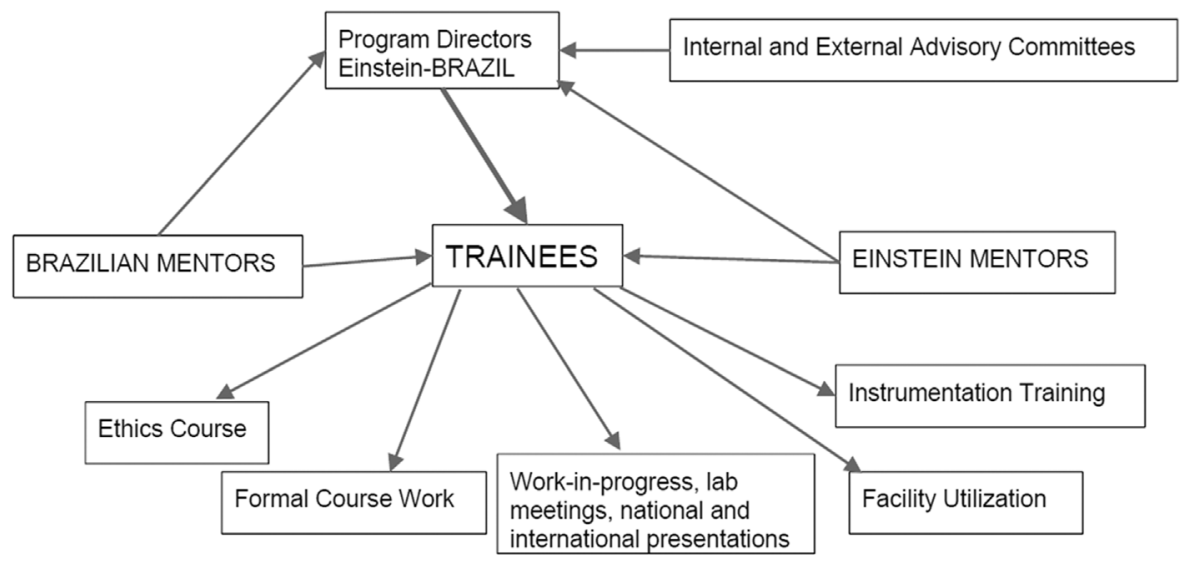

Figure 3 - The model used by the Einstein-Brazil Fogarty program to ensure dynamic, ongoing contributions by both Einstein and Brazilian mentors to the successful experiences of the trainees, including oversight of the program by US and Brazilian scientists at outside institutions.

ical, social, and behavioral research; responsible conduct of scientific research; the role and functions of Institutional Review Boards; vulnerable populations of research subjects; issues in AIDS and human genetics research; international research conducted in developing countries; and other special topics determined by the research activities of the students enrolled. Students review research protocols and use them to assess the risk levels for various research maneuvers, devise informed consent forms, and provide the type of evaluations made by IRBs. Past and current controversies in research ethics are examined. This course also has sessions on ethics in animal research. The Einstein fac- ulty and the Brazilian students have consistently felt that this course brings forth critical aspects of the research experience that need increased global attention.

The Brazilian trainees also completed training in the humane and appropriate use of laboratory animals in research. These courses are led by veterinarians in Einstein's Institute for Animal Studies, which holds international accreditation through the Association for Assessment and Accreditation of Laboratory Animal Care International. This training expands on the practical and ethical issues involved in animal research. In addition to in-person sessions, the students complete the Collaborative Institutional 
Training Initiative (CITI) computer-based training program (https://www.citiprogram.org/). Through the Animal Institute, the trainees learn methods for the safe and humane handling of rodents and the procedures for anesthesia, analgesia, euthanasia, and sterile surgery on rodents.

The Fogarty trainees had access to all of Einstein's diverse scientific resources available to them. The major shared facilities and cores are described at https://www.einstein.yu.edu/research/shared-facilities/. Over the years, students have performed work within nearly all of the services available. An important aspect of the trainees' work in these centers has been that the skills learned are brought back to Brazil for future application.

The Fogarty also leverages the availability of diverse Graduate-level courses at Einstein. The Brazilian trainees have had opportunities to take courses taught in both the Graduate and Medical Schools at Einstein, such as Medical Microbiology and Infectious Diseases, Medical Parasitology and Global Health, Microbial Pathogenesis, Mechanisms of Disease, Glycobiology, Molecular and Cellular Neuroscience, Bioinformatics, etc. The Brazilian students can also participate in "Clinical Research 101", which teaches the fundamentals of clinical and translational research. In the event that a student wished to formally improve their English, we provided trainees with the opportunity to attend courses at Lehman College's English Program. The students all attended their departmental works-in-progress as well as journal clubs, such as the Emerging Diseases Journal Club and the Immunology Journal Club.

The trainees all formally participated in the laboratory meetings of their mentor as well as in group meetings, either at the departmental level or with groups of researchers focusing on the same pathogen. At the completion of their training period at Einstein, the Brazilian students all presented their work at special seminars. These programs are open to the Einstein community and are well attended by the Einstein Faculty of the Fogarty and members of the trainee's laboratory and department as well as by the numerous friends that each student makes in the course of their experiences at Einstein. Each student is provided feedback from their laboratory mentor in an ongoing manner (typically monthly) and at the completion of their tenure at Einstein. The research activities of the trainees are also reviewed prospectively by the Einstein Fogarty leadership.

\section{Highlights of Fogarty Trainees' Achievements}

The following Brazilian trainees are highlighted for the quality and impact of their work during their research experiences at Einstein. Table 1 provides a complete list of the Einstein Fogarty trainees.

\section{Fungi}

Fungi are among the most common microbes encountered by humans. Brazil's rich and diverse lands in combi- nation with the increased population size, expansion into new regions, and increased numbers of immunocompromised individuals has led to a dramatic increase in fungal infections in this nation over the past 20 years (Colombo et al., 2011; Sifuentes-Osornio et al., 2012). In Brazil, fungal diseases account for a large proportion of deaths due to infectious diseases, especially in the setting of HIV co-infection (Prado et al., 2009). The following highlights the major accomplishments of the Brazilian Fogarty trainees focusing on mycology.

\section{Histoplasma capsulatum}

Arriving in Einstein in 2006, Allan Jefferson Guimarães was the first Fogarty trainee to work on fungi. Allan was a graduate student from the laboratory of Rosely M. Zancope-Oliveira, $\mathrm{PhD}$ at Fiocruz in Rio de Janeiro. In the Nosanchuk laboratory, Allan successfully generated monoclonal antibodies (mAbs) to a cell surface immunodominant protein, heat shock protein 60 (HSP60). Allan used these mAbs to develop new approaches for diagnosis as well as to define innovative approaches to modify lethal experimental histoplasmosis (Guimaraes et al., 2009, 2011). During his experience at Einstein, Allan published a remarkable 21 articles with Dr. Nosanchuk (Albuquerque et al., 2012; Bryan et al., 2012; Guimaraes et al., 2006, 2008, 2009, 2010, 2010b, 2011, 2011b, 2011c, 2011d; Fabrizio et al., 2010; Lopes et al., 2010, 2010b; Nemeth et al., 2014; Nosanchuk et al., 2012; Oliveira et al., 2010; Peerzada et al., 2013; Revskaya et al., 2009; Thomaz et al., 2013), presented at international meetings (eg. ASM), and attended the prestigious Woods Hole Course in Molecular Mycology. Upon completing his $\mathrm{PhD}$, Dr. Guimarães returned to Brazil for a post-doctoral fellowship and he currently is a professor in the Fluminense Federal University.

During a sabbatical in 2005 from the Federal University of Rio de Janeiro (UFRJ) that he spent at Einstein, Professor Marcio Rodrigues made a remarkable discovery when he found that the pathogenic fungus Cryptococcus neoformans produced extracellular vesicles that were rich in components associated with virulence (Rodrigues et al., 2007, 2008). In 2007, Priscila Costa Albuquerque arrived from Dr. Zancope-Oliveira's laboratory to work in the Nosanchuk group at Einstein. Although she initially successfully studied the effect of mAbs on $H$. capsulatum pathogenesis (Shi et al., 2008), Priscilla turned her focus to determine whether extracellular vesicle production was isolated to C. neoformans and she found that extracellular vesicle release is a process that occurs in diverse fungi (Albuquerque et al., 2008). This work combined with the earlier findings by Dr. Rodrigues has led to an enormous explosion of research into the conserved biological process. While at Einstein, Priscila participated in a specialty course at the CDC entitled Laboratory Identification of Emerging Pathogenic Molds. Notably, Priscila is currently a senior post-doctoral scientist in Dr. Rodrigues' group at UFRJ and 
Table 1 - List of Brazilian Fellows participating in the Einstein-Brazil Fogarty.

\begin{tabular}{|c|c|c|c|c|}
\hline Name & Date & Brazilian Mentor & US Mentor & Current Position \\
\hline Rocha, Leonardo & 2004-2005 & Soares & Tanowitz & $\begin{array}{l}\text { Ph.D. student and an M.D., Intensive Care Unit at } \\
\text { the Hospital Israelita Albert Einstein }\end{array}$ \\
\hline Fortes, Fabio & 2004-2005 & Campos de Carvalho & Tanowitz/Spray & $\begin{array}{c}\text { Associate Professor of Physiology and Biophys- } \\
\text { ics, State University of West Zone of Rio de Ja- } \\
\text { neiro }\end{array}$ \\
\hline Goldenberg, Regina & 2004-2005 & Campos de Carvalho & Spray/Tanowitz & Associate Professor, UFRJ \\
\hline Santos Andrade, Daniele & 2005 & Scharfstein & Tanowtiz & Postdoctoral Fellow, UFRJ \\
\hline Guimaraes, Allan & 2005-2006 & Zancopé-Oliveira & Nosanchuk & $\begin{array}{c}\text { Assistant Professor, Federal University of } \\
\text { Fluminense, Niteroi }\end{array}$ \\
\hline Alberto, Anael & 2006 & Alves & Spray/Scemes & Postdoctoral Fellow, Fiocruz \\
\hline Paes, Rodrigo & 2006-2007 & Zancopé-Oliveira & Nosanchuk & Government Employee, FIOCRUZ \\
\hline De Almeida, Cecilia & 2004-2008 & & Tanowitz & Researcher, Fiocruz \\
\hline Ferreira, Anna Beatriz & 2006 & Euzanir Sarno & Spray/Jacobs & Graduate Student, Fiocruz \\
\hline Guedes, Herbert & $2007-2008$ & Zancopé Oliveira & Nosanchuk & Professor, UFRJ \\
\hline Lang, Elza & 2006 & Marques & Steinman & $\begin{array}{l}\text { Postdoctoral researcher, Ribeirao Preto Medical } \\
\text { School, University of Sao Paulo }\end{array}$ \\
\hline Del Corsso, Cristiane & 2007 & Campos de Carvalho & Spray & Associate Professor, UFRJ \\
\hline Diaz, Fernando & 2008 & Diaz, Fernando & 2008 & Postdoctoral Researcher, University of Sao Paulo \\
\hline $\begin{array}{l}\text { Adesse Petra Mar- } \\
\text { tins, Daniel }\end{array}$ & 2008 & Rosalia Mendez-Otero & Spray/Tanowitz & Associate Professor, Oswaldo Cruz Foundation \\
\hline Italiani, Valeria & 2008-2009 & Marques & Steinman & $\begin{array}{l}\text { Professor and Researcher Paulista University - } \\
\text { Campus Ribeirão Preto }\end{array}$ \\
\hline Lopes, Livia & 2008-2009 & Barreto-Bergter & Nosanchuk & Assistant Professor, UFRJ \\
\hline Munez, Mauro & 2008-2009 & Zancopé-Oliveira & Nosanchuk & Staff Scientist, FioCruz \\
\hline Mello, Debora & 2008-2009 & Campos de Carvalho & Spray/Tanowitz & Postdoctoral Researcher, UFRJ \\
\hline Acquarone, Mariana & 2008-2009 & Santos Barbosa & Spray/Weiss & Postdoctoral Researcher, Fiocruz \\
\hline Celes, Maria Rubia & 2009-2010 & Rossi & Tanowitz/Jelicks & \\
\hline De Cerqueira, Mariana & 2009-2010 & Nimrichter & Nosanchuk & Molecular Devices, Brazil \\
\hline Jasmin & 2009-211 & Mendez-Otero & Spray/Jelicks & Postdoctoral researcher, UFJF \\
\hline Oliveira, Debora & 2009 & Rodrigues & Nosanchuk/Casadevall & Postdoctoral researcher, Fiocruz, RJ \\
\hline Prado, Cibele & 2009-2010 & Rossi & Tanowitz/Jelicks & $\begin{array}{l}\text { Young Investigator, Ribeirao Preto School of } \\
\text { Medicine, University of Sao Paulo }\end{array}$ \\
\hline Da Silva, Ana Carolina & 2010-2011 & Neio Lucio Boechat & Jacobs & Associate Professor, UFRJ \\
\hline Nardelli, Sheila Cristina & 2010-2011 & Schenkman & Kami Kim & Visitor Researcher, Carlos Chagas Institute \\
\hline Pereira Bruno, Fernando & 2010-2011 & Mendez-Otero & Desruisseaux/Spray/Weiss & Medical Residency \\
\hline Tavares, Patricia & 2011 & Nimrichter & Nosanchuk & Postdoctoral Fellow, UFRJ \\
\hline Thomas, Luciana & 2011 & Taborda & Nosanchuk & Postdoctoral Fellow, University of Sao Paulo \\
\hline De Abreu, Susana & 2011 & Campos de Carvalho & Spray & Graduate Student, UFRJ \\
\hline Nascimento, Ariane & 2011-2012 & Bagagli & Nosanchuk & Postdoctoral Fellow, University of Sao Paulo \\
\hline Nimrichter, Leonardo & 2008-2009 & Travassos & Nosanchuk & Associate Professor, UFRJ \\
\hline $\begin{array}{l}\text { Nogueira De } \\
\text { Almeida, Larissa }\end{array}$ & 2011-2012 & Scharfstein & Santambrosio & Postdoctoral Fellow, UFRJ \\
\hline Petrs Silva, Hilda & 2011 & Linden & Spray, Tanowitz & Associate Professor, UFRJ \\
\hline $\begin{array}{l}\text { Braga da Costa } \\
\text { Reis, Marcella }\end{array}$ & 2012-2013 & Mendez-Otero & Spray/Tanowitz & Postdoc, UNIFESP \\
\hline Martins, Yuri & $2012-2013$ & Carvalho & Desruisseux & Medical Residency \\
\hline Saraiva Freitas, Dayvison & $2012-2013$ & Rosely Zancope & Nosanchuk & Postdoctoral Fellow in Microbiology, Fiocruz \\
\hline $\begin{array}{l}\text { Silva-Souza, Hercules } \\
\text { Antonio }\end{array}$ & 2013-2014 & Persechini & Tanowitz/Scemes & Graduate Student, UFRJ \\
\hline Santos, Tatiana & 2013 & Vommaro & Tanowitz/Weiss & Postdoctoral Fellow, UFRJ \\
\hline Rizzo, Juliana & 2013-2014 & Rodrigues & Nosanchuk & Graduate student, UFRJ \\
\hline Tardelli, Mirela & 2014 & Nimrichter & Nosanchuk & Undergraduate student, UFRJ \\
\hline Vargas Cesar, Gabriele & 2014-2015 & Nimrichter & Nosanchuk & Graduate student, UFRJ \\
\hline De Menezes, Laura & 2014-2015 & Rozental & Spray & Graduate Student, UFRJ \\
\hline
\end{tabular}


Fiocruz. Dr. Rodrigues also organized the training of Leonardo Nimrichter, $\mathrm{PhD}$ in the Nosanchuk laboratory. Arriving in 2011, Dr. Nimrichter expanded our understanding of the impact of extracellular vesicles on the pathobiology of human opportunistic fungi, and Drs. Nimrichter and Nosanchuk have 13 co-author publications to date arising from this collaboration (Albuquerque et al., 2012; Guimaraes et al., 2010, 2011b, 2011d; Nosanchuk et al., 2008; Oliveira et al., 2010, 2010b; Nguyen et al., 2012; Rodrigues et al., 2007, 2008, 2008b, 2011).

In 2007, Herbert Guedes, a predoctoral student, arrived from the Zancope-Oliveira group to develop a Pichia pastoris system in the Nosanchuk laboratory. Herbert effectively optimized this system to produce exoantigens from H. capsulatum and Leishmania spp. and used these to define the biological function of an immunodominnat protein in H. capsulatum (Guimaraes et al., 2008) and demonstrate the protective function of an extracellular protease in Leishmania amazonensis (Guedes et al., 2014). Dr. Guedes is currently a professor in the UFRJ.

Professor Rodrigues arranged for two sequential students to study additional mAbs to $H$. capsulatum in Dr. Nosanchuk's laboratory. Livia Lopes, starting at Einstein in 2008, and Mariana Cerqueira, arriving in 2009, demonstrated that simply binding to the fungal cell surface was not sufficient to mediate protection (Lopes et al., 2010), a finding in direct contradiction to assumptions by critics of prior antibody based work in this fungus. Interestingly, Livia also demonstrated that mAbs to Scedosporium apiospermum enhanced pathogenicity (Lopes et al., 2010) and that sodium butyrate inhibits pathogenic yeasts (Nguyen et al., 2011). Dr. Lopes is currently a professor at UFRJ. Mariana published two more papers pertaining to the biology of H. capsulatum with Dr. Nosanchuk (Guimaraes et al., 2011, 2011b). Notably, Mariana Cerqueira and Dr. Guimarães were married in Rio de Janeiro in 2013, demonstrating an unexpected but nevertheless welcome synergy of the Einstein Fogarty program.

\section{Sporothrix species}

Sporotrichosis is a mycosis that rapidly emerged in Brazil over the course of the Fogarty program (Barros et al., 2011). Remarkably, a hypervirulent presentation has arisen especially in patients with contact with infected cats especially in Rio de Janeiro state and these infections are generally due to the newly identified species Sporothrix brasiliensis (Oliveira et al., 2014; Rodrigues et al., 2013). In 2006, Rodrigo de Almeida Paes came from Dr. Zancope-Oliveira's group to the Nosanchuk laboratory where he successfully developed new serodiagnostic methods for improving the ability of clinicians to combat this epidemic (Almeida-Paes et al., 2007, 2007b). Additionally, he discovered new information about melanin production, a virulence factor, in Sporothrix species (Almeida-Paes et $a l .$, 2009). Dr. Paes is a professor and the Head of the My- cological Diagnosis Section of the Mycology Laboratory, Fiocruz Rio de Janeiro. Following on Rodrigo's success, Dayvison Freitas, MD, a dermatologist who in 2012 was working towards his $\mathrm{PhD}$ at Fiocruz in Rio de Janeiro, came to the Nosanchuk laboratory to explore virulence characteristics in the newly identified species Sporothrix brasiliensis. Dr. Freitas has characterized the evolution of virulence in chronic sporotrichosis by studying serial isolates from patients (Freitas et al., 2015). Dr. Freitas is now on staff as a research physician at Fiocruz

In conclusion, Brazilian trainees on the Einstein Fogarty have made fundamental contributions to mycology. These students have developed innovative diagnostic methods for fungal pathogens, demonstrated new mechanisms for disease modifications by mAbs, created new model systems for studying pathogenesis, defined the emergence of virulence in chronic human fungal disease, and made several fundamental observations about fungal biology.

\section{Parasites}

Parasitic diseases remain a major threat to human health in Brazil. Significant diseases in diverse regions of Brazil include American trypanosomiasis due to Trypanosoma cruzi, malaria due to Plasmodium falciparum and/or P. vivax, and toxoplasmosis (www.cdc.org), and these infections were the focus of a large group of Brazilian trainees' research at Einstein. The following presents major successes of the Brazilian Fogarty trainees applying themselves in parasitology laboratories.

\section{Trypanosoma cruzi}

A major area of research by the Brazilian trainees was the study of stem cells in murine Chagas models. Arriving in August of 2004, Professor Antonio Campos de Carvalho's post-doctoral student Regina Goldenberg, $\mathrm{PhD}$ was the first Einstein Fogarty trainee. Working in collaboration with Drs. Tanowtiz, Spray and Linda Jelicks, Dr. Goldenberg used MRI to analyze functional characteristics of hearts in chronically $T$. cruzi-infected mice as well as analyzed whether bone marrow stem cell therapy improves functional MRI parameters. In addition, she studied the effects of $T$. cruzi infection on gap junction and purinergic receptor expression in hearts of infected mice and in cultures of cardiac myocytes. Finally, Dr. Goldenberg investigated changes in gene expression in acutely infected cultures of cardiac myocytes. Altogether, her work at Einstein resulted in 7 publications (Adesse et al., 2011; Campos de Carvalho et al., 2009; Goldenberg et al., 2008, 2009; Lachtermacher et al., 2012; Soares et al., 2010, 2011) that have significantly expanded our knowledge of $T$. cruzi pathobiology and provided Regina with a large skill set that she currently applies as a professor at UFRJ. Working with and building upon the studies of Dr. Goldenberg in the Tanowitz laboratory, Leonardo Lima Rocha, a graduate student, arrived at 
Einstein in 2004 from the laboratory of Ricardo Ribeiro dos Santos, MD at Fiocruz, Salvador, Bahia. In a series of 4 papers, Dr. Rocha assisted in demonstrating that gene expression is differentially regulated after stem cell therapy in chagasic cardiomyopathy (Goldenberg et al., 2008, 2009; Soares et al., 2010, 2011). Dr. Rocha currently works in the Intensive Care Unit of the Hospital Israelita Albert Einstein in São Paulo. Also arriving in 2004 from the laboratory of Dr. Campos de Carvalho, Fabio Fortes, a predoctoral trainee, worked in Dr. Spray's laboratory collaborating on the studies of transplantation on chagasic heart disease (Adesse et al., 2011; Goldenberg et al., 2008; Lachtermacher et al., 2012) Dr. Fortes is currently a professor at the State University of West Zone of Rio de Janeiro. In 2009, Jasmin, a pre-doctoral student from the Campos de Carvalho group at UFRJ, worked with Drs. Spray and Jelicks where she focused on mesenchymal stem cells in chagasic cardiomyopathy models (Jasmin et al., 2010, 2011, 2012, 201b), where she developed methods for tracking cells by innovative imaging methodologies. She is currently a post-doctoral researcher at UFRJ.

Another of the first students, Cecília de Almeida, $\mathrm{PhD}$, arrived in 2004 to begin post-doctoral training in the laboratories of Drs. Michael Lisanti and Tanowitz. She has published 7 papers with the Einstein investigators (Bonuccelli et al., 2005; Combs et al., 2005; de Almeida et al., 2011; Hassan et al., 2006; Medina et al., 2006, 2007; Nagajyothi et al., 2008). Her primary work significantly expanded our knowledge of caveolins in infection (de Almeida et al., 2011; Medina et al., 2006, 2007) and she also made fundamental observations in the role of adipocytes in the pathogenesis of Chagas disease (Combs et al., 2005; Nagajyothi et al., 2008), which was a new area of investigation in this field. Dr. Almeida is currently a professor at Fiocruz, Rio de Janiero. In 2005, Daniele dos Santos Andrade, a graduate student from Julio Scharfstein's lab at UFRJ participated in the study of cyclin and caveolin in a murine chagasic myocarditis model in the Tanowitz laboratory and found that the cardiac disease is affected by changes in cell cycle proteins and that endothelium pathway upregulation enhances mortality (Nagajyothi et al., 2006). Additionally, her findings subsequently demonstrated that $T$. cruzi invades host cells through the activation of endothelin as well as bradykinin receptors (Andrade et al., 2012). Dr. Santos Andrade is currently a postdoctoral fellow at UFRJ. Arriving in the Tanowitz and Spray laboratories in 2008, Daniel Adesse Martins, a pre-doctoral student from UFRJ, produced 4 first author papers (Adesse et al., 2008, 2010, 2010b, 2011). Daniel found that T. cruzi induces alterations in connexin 43 (Adesse et al., 2008) and reduces expression of caveolin-3 (Adesse et al., 2010b) in cardiac tissues. Additionally, using transcriptomic signatures, he demonstrated that infection with different strains of $T$. cruzi altered similar though not identical host cell pathways (Adesse et al., 2010). Dr. Martins is now a pro- fessor at Fiocruz, Rio de Janeiro. In 2009, Mara Celes PhD., a post-doctoral fellow from Dr. Marcos Rossi's laboratory at University of Sao Paulo, Ribeirao Preto, participated in research with Drs. Tanowitz and Jelicks during which she explored mechanisms of coronary microvascular disease in chronic Chagas disease (Rossi et al., 2010) and identified that dystrophin disruption occurs early in Chagas cardiomyopathy to significantly adversely impact mortality (Malvestio et al., 2014; Prado et al., 2012). Moreover, Dr. Celes used her knowledge gained in the course of these experiments to develop a model of sepsis in which she demonstrated that cardiomyocyte structural and functional changes are associated with disruption of homeostasis, which can be ameliorated by the administration of calcium channel blockers (Celes et al., 2013). Dr. Celes is currently a professor at the Federal University of Goiás.

\section{Plasmodium species}

In 2010, Fernando Pereira Bruno, MD joined a collaborative project with Drs. Mahalia Desruisseaux, Weiss, Tanowitz and Spray on the study of neuro-cognitive function in the setting of cerebral malaria. Using a murine model, Dr. Bruno showed that a dysregulation in Akt signaling was associated with neurological sequela after infection with Plasmodium berghei and that the defects in cognition could be significantly improved by lithium treatment (Dai et al., 2012). Additionally, Dr. Bruno demonstrated that a novel agent being studied by this group, HJP-272, in combination with artemisinin could synergistically enhance survival and reduce brain hemorrhage in their model (Dai et al., 2012b).

\section{Toxoplasma gondii}

In 2010, Sheila O. Nardelli, PhD, joined the laboratory of Kami Kim, MD, from the laboratory of Dr. Sergio Schenkman at UNIFESP to study epigenetic regulation in $T$. gondii. Her findings have provided us with the first large-scale characterization of the histone code in this parasite (Nardelli et al., 2013), which is a significant first step in defining how genes are epigenetically regulated in this pathogen (Croken et al., 2012). Dr. Nardelli is currently a visiting researcher at Fiocruz, Curitiba.

Overall, the Brazilian Fogarty trainees generated significant new information about the pathobiology of Chagas disease, malaria and toxoplasmosis. The students learned classic techniques as well as cutting edge methodologies to accelerate their research. These students characterized the efficacies of stem cell therapies, identified targets for future development as therapeutic targets, evaluated the efficacy of drug combinations, and made fundamental observations about parasite biology.

\section{Bacteria}

The Fogarty also supported interesting work on the pathogenesis and biology of Mycobacterium species as 
well as on invasion of Legionella pneumophilia. Significant incentive for these studies arose from the expertise of the Spray laboratory in the structure/function of gap junctions (see above) that could be applied to bacterial pathogenesis studies. In 2006, Anael Alberto, a graduate student from Professor Luiz Alves' laboratory in Fiocruz worked in the Spray laboratory on the ionotropic P2X7 receptor, a member of the ATP-gated purinergic receptors, that has been reported to play an important role in the activation of the immune system. Dr. Alberto showed that P2X7 receptors expressed in macrophage cell lines display different degrees of membrane permeabilization in the setting of infection with Mycobacterium tuberculosis and that tyrosine kinase signal transduction was a mediator of these effects (Iglesias et al., 2008). Dr. Alberto is currently a postdoctoral researcher at Fiocruz. In 2012, Hercules da Silva Souza, a pre-doctoral student from Pedro Persechini's laboratory at UFRJ, further investigated specific roles of P2X7 as it relates to apoptosis and the impact of bioactive lipids. In particular, Hercules investigated the participation of pannexin 1 in the mechanism of transmembrane transport and inflammasome formation induced by inhibitors of eicosanoid synthesis (Silva-Souza et al., 2014). Hercules successfully concluded his graduate studies at UFRJ. The role of host cells was also investigated by Larissa Nogueira de Almeida, a pre-doctoral Student, from Professor Scharfstein's group, who joined the laboratory of Professor Laura Santambrogio in 2011. With Dr. Santambrogio, Larissa found that the immune response was significantly adversely impacted by previously unrecognized agedependent alterations in cellular proteostasis (Cannizzo et al., 2012). This new finding underscores the damage potential of endosomal accumulation of oxidatively modified proteins. Dr. Nogueira de Almeida is currently a postdoctoral fellow at UFRJ.

Also in 2006, Anna Beatriz Robottom Ferreira, a graduate student in the laboratory of Professor Milton Ozorio Moraes at Fiocruz, Rio de Janeiro, worked with both Dr. Spray and Dr. William Jacobs, a member of the US National Academy of Sciences. Anna trained in the Einstein microarray facility and conducted microarray experiments to further understand the pathogenesis of leprosy, which subsequently led to a publication detailing specific chemokine, mitochondrial and lipid metabolism processes in $M y$ cobacterium leprae (Guerreiro et al., 2013). Similarly, in 2010, Anna Carolina da Silva Carvalho, a pre-doctoral student from the group of Dr. Marcus Conde in UFRJ, worked in the Jacobs laboratory developing mycobacteriophage from shuttle phasmids and mastering other techniques that she brought back to her group in Brazil. Dr. Silva Carvalho is currently a professor at UFRJ.

In 2006, Elza Lang, $\mathrm{PhD}$ joined the laboratory of $\mathrm{Dr}$. Howard Steinman as a post-doctoral researcher to define specific aspects of the invasion of Legionella pneumophila. Dr. Lang's work demonstrated that invasion of amoebae is enhanced by the presence of a Type IV secretion system in the bacterium (Bandyopadhyay et al., 2013). Dr. Lang is currently a postdoctoral researcher in the University of São Paulo, Ribeirão Preto.

Hence, Brazilian Fogarty trainees at Einstein made new discoveries about immune activation, oxidative toxicities, apoptosis and cell signaling. Moreover, the trainees have brought diverse techniques back to their intuitions to apply in ongoing projects.

\section{Summary}

The Einstein Fogarty program has resulted in a remarkable decade of collaborative research with concomitant training of 43 young Brazilian scientists who have successfully transitioned along pathways that have significantly augmented the pursuit of scientific discovery in Brazil. The work accomplished by the Brazilian Fogarty trainees has resulted in nearly 100 peer-reviewed publications to date as well as several book chapters. The Brazilian trainees have been invited speakers at Einstein as well as national and international conferences to present their studies performed during their Fogarty fellowships. The vast majority of trainees have continued on successful pathways to careers as independent scientists, with 14 individuals already having professor positions.

Importantly, the interactions of the US investigators with their counterparts in Brazil have not been limited to activities in New York. In fact, with the support of the Fogarty grant, Drs. Spray, Tanowitz and Nosanchuk have each made several trips to different institutions within Brazil as well as participated in local, national and international scientific congresses in Brazil. In addition, the Brazilian Fogarty leadership has also made several trips to the US and given well-attended lectures at Einstein. Moreover, several past trainees have returned to Einstein for additional short-term, collaborative scientific training experiences as well as further solidifying ongoing interactive research efforts and establishing new areas of investigation.

The Einstein members are committed to continuing their efforts with Brazilian scientists. This is consistent with the longstanding collaborations that are embodied in particular by the efforts of Drs. Spray and Tanowitz. Dr. Spray has in fact served as a Visiting Professor at the Institute of Biophysics "Carlos Chagas Filho" since 1988. It is notable that Dr. Spray was inducted as a Corresponding Member into the Brazilian Academy of Sciences in 1995 and that this honor was also awarded to Dr. Herbert Tanowitz during the course of the Fogarty, being inducted in 2010 (Figure 4). This rich tradition of exchange has continued with Dr. Nosanchuk serving as a Visiting Professor with the Brazilian Scientific Mobility Program since 2012 and as a Visiting Researcher at the Center for Technological Development in Health (CDTS) at Fiocruz, Rio de Janiero since 2013. This concise review of the EinsteinBrazil Infectious Diseases Fogarty program has been writ- 


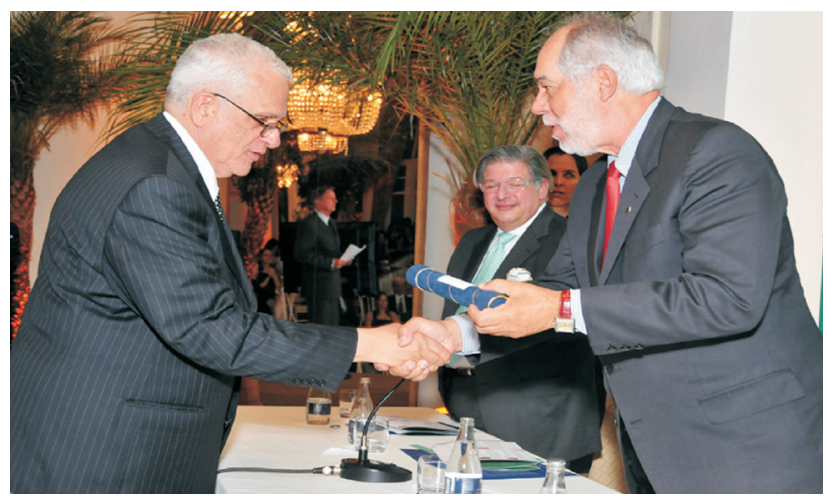

Figure 4 - Herbert Tanowitz, MD receiving his formal certificate as a Corresponding Member of the Brazilian Academy of Sciences from Professor Jorge Almeida Guimarães, president of CAPES, Brazilian Ministry of Education in April 2010.

ten to encourage future collaborative efforts between Brazil and the US as well as other global partners.

\section{Acknowledgments}

The success of the Einstein Fogarty award was in large part due to the enthusiastic and dedicated efforts of the trainees of the program. We extend our deep gratitude to Ms. Frances Andrade as well as the members of the Pathology Departmental office and the Office of International Services at Einstein for assisting us with coordinating the stays of the Brazilian Fogarty awardees in New York. We also acknowledge the generous, ongoing support provided to the Brazilian investigators by their government for continued collaborative efforts with the US and other international scientists. In addition, we acknowledge the early enthusiasm of the late Dr. Marshall Horowitz for our submission of the initial proposal. Support for all of the participants of the Einstein Fogarty program was in part through NIH Fogarty International Training Centers Interhemispheric Research/Training in Infectious Diseases D43TW007129. MLR, LN and ACCC are also supported by grants from the Brazilian agencies Fundação de Amparo à Pesquisa do Estado do Rio de Janeiro (FAPERJ), Conselho Nacional de Desenvolvimento Científico e Tecnológico (CNPq), Ministry of Health (DECIT) and Coordenação de Aperfeiçoamento de Pessoal de Nível Superior (CAPES). JDN is supported in part through the US-Brasil NIH supplement R37 AI033142-23.

\section{References}

Adesse D, Garzoni LR, Huang H et al. (2008) Trypanosoma cruzi induces changes in cardiac connexin43 expression. Microbes Infect 10:21-28.

Adesse D, Goldenberg RC, Fortes FS et al. (2011) Gap junctions and chagas disease. Adv Parasitol 76:63-81.

Adesse D, Iacobas DA, Iacobas S et al. (2010) Transcriptomic signatures of alterations in a myoblast cell line infected with four distinct strains of Trypanosoma cruzi. Am J Trop Med Hyg 82:846-854.

Adesse D, Lisanti MP, Spray DC et al. (2010b) Trypanosoma cruzi infection results in the reduced expression of caveolin-3 in the heart. Cell Cycle 9:1639-1646.

Albuquerque PC, Cordero RJ, Fonseca FL et al. (2012) A Paracoccidioides brasiliensis glycan shares serologic and functional properties with cryptococcal glucuronoxylomannan. Fungal Genet Biol 49:943-954.

Albuquerque PC, Nakayasu ES, Rodrigues ML et al. (2008) Vesicular transport in Histoplasma capsulatum: an effective mechanism for trans-cell wall transfer of proteins and lipids in ascomycetes. Cell Microbiol 10:1695-1710.

Almeida-Paes R, Frases S, Fialho-Monteiro RC et al. (2009) Growth conditions influence melanization of Brazilian clinical Sporothrix schenckii isolates. Microbes Infect 11:554562.

Almeida-Paes R, Pimenta MA, Monteiro PC et al. (2007) Immunoglobulins G, M and A against Sporothrix schenckii exoantigens in patients with sporotrichosis before and during treatment with itraconazole. Clin Vaccine Immunol 14:1149-1157.

Almeida-Paes R, Pimenta MA, Pizzini CV et al. (2007b) Use of mycelial-phase Sporothrix schenckii exoantigens in an enzyme-linked immunosorbent assay for diagnosis of sporotrichosis by antibody detection. Clin Vaccine Immunol 14:244-249.

Andrade D, Serra R, Svensio E et al. (2012) Trypanosoma cruzi invades host cells through the activation of endothelin and bradykinin receptors: a converging pathway leading to chagasic vasculopathy. Br J Pharmacol 165:1333-1347.

Bandyopadhyay P, Lang EA, Rasaputra KS et al. (2013) Implication of the VirD4 coupling protein of the Lvh type 4 secretion system in virulence phenotypes of Legionella pneumophila. J Bacteriol 195:3468-3475.

Barros MB, de Almeida-Paes R, Schubach AO (2011) Sporothrix schenckii and Sporotrichosis. Clin Microbiol Rev 24:633654.

Bonuccelli G, Sotgia F, Frank PG et al. (2005) ATR/TEM8 is highly expressed in epithelial cells lining Bacillus anthracis' three sites of entry: implications for the pathogenesis of anthrax infection. Am J Physiol Cell Physiol 288:C1402-1410.

Bryan RA, Guimaraes AJ, Hopcraft S et al. (2012) Toward developing a universal treatment for fungal disease using radioimmunotherapy targeting common fungal antigens. Mycopathologia 173:463-471.

Campos de Carvalho AC, Goldenberg RC, Jelicks LA et al. (2009) Cell Therapy in Chagas Disease. Interdiscip Perspect Infect Dis 2009:484358.

Cannizzo ES, Clement CC, Morozova K et al. (2012) Age-related oxidative stress compromises endosomal proteostasis. Cell Rep 2:136-149.

Celes MR, Malvestio LM, Suadicani SO et al. (2013) Disruption of calcium homeostasis in cardiomyocytes underlies cardiac structural and functional changes in severe sepsis. PLoS One 8:e68809.

Colombo AL, Tobon A, Restrepo A et al. (2011) Epidemiology of endemic systemic fungal infections in Latin America. Med Mycol 49:785-798. 
Combs TP, Nagajyothi S, Mukherjee S et al. (2005) The adipocyte as an important target cell for Trypanosoma cruzi infection. J Biol Chem 280:24085-24094.

Croken MM, Nardelli SC, Kim K (2012) Chromatin modifications, epigenetics, and how protozoan parasites regulate their lives. Trends Parasitol 28:202-213.

Dai M, Freeman B, Bruno FP et al. (2012b) The novel ETA receptor antagonist HJP-272 prevents cerebral microvascular hemorrhage in cerebral malaria and synergistically improves survival in combination with an artemisinin derivative. Life Sci 91:687-692.

Dai M, Freeman B, Shikani HJ et al. (2012) Altered regulation of Akt signaling with murine cerebral malaria, effects on longterm neuro-cognitive function, restoration with lithium treatment. PLoS One 7:e44117.

de Almeida CJ, Witkiewicz AK, Jasmin JF et al. (2011) Caveolin-2-deficient mice show increased sensitivity to endotoxemia. Cell Cycle 10:2151-2161.

Fabrizio K, Manix C, Guimaraes GJ et al. (2010) Aggregation of Streptococcus pneumoniae by a pneumococcal capsular polysaccharide-specific human monoclonal IgM correlates with antibody efficacy in vivo. Clin Vaccine Immunol 17:713-721.

Frietas DF, Santos SS, Almeida-Paes R et al. (2015) Increase in virulence of Sporothrix brasiliensis over five years in a patient with chronic disseminated sporotrichosis. Virulence 6:112-120.

Goldenberg RC, Iacobas DA, Jacobas S et al. (2009) Transcriptomic alterations in Trypanosoma cruzi-infected cardiac myocytes. Microbes Infect 11:1140-1149.

Goldenberg RC, Jelicks LA, Fortes FS et al. (2008) Bone marrow cell therapy ameliorates and reverses chagasic cardiomyopathy in a mouse model. J Infect Dis 197:544-547.

Guedes HL, Costa BLS, Chaves SP et al. (2014) Intranasal vaccination with extracellular serine proteases of Leishmania amazonensis confers protective immunity to BALB/c mice against infection. Parasites and Vectors 7:448.

Guerreiro LT, Robottom-Ferreira AB, Ribeiro-Alves M et al. (2013) Gene expression profiling specifies chemokine, mitochondrial and lipid metabolism signatures in leprosy. PLoS One 8:e64748.

Guimaraes AJ, de Cerqueira MD, Nosanchuk JD (2011) Surface architecture of Histoplasma capsulatum. Front Microbiol 2: 225.

Guimaraes AJ, Frases S, Cordero RJ et al. (2010) Cryptococcus neoformans responds to mannitol by increasing capsule size in vitro and in vivo. Cell Microbiol 12:740-753.

Guimaraes AJ, Frases S, Gomez GJ et al. (2009) Monoclonal antibodies to heat shock protein 60 alter the pathogenesis of Histoplasma capsulatum. Infect Immun 77:1357-1367.

Guimaraes AJ, Frases S, Pontes B et al. (2011b) Agglutination of Histoplasma capsulatum by IgG monoclonal antibodies against Hsp60 impacts macrophage effector functions. Infect Immun 79:918-927.

Guimaraes AJ, Hamilton AJ, de M Guedes HL et al. (2008) Biological function and molecular mapping of $\mathrm{M}$ antigen in yeast phase of Histoplasma capsulatum. PLoS ONE 3:e3449.

Guimaraes AJ, Martinez LR, Nosanchuk JD (2011c) Passive administration of monoclonal antibodies against $H$. capsulatum and other fungal pathogens. J Vis Exp 48:2532.
Guimaraes AJ, Nakayasu ES, Sobreira TJ et al. (2011d) Histoplasma capsulatum heat-shock 60 orchestrates the adaptation of the fungus to temperature stress. PLoS One 6:e14660.

Guimaraes AJ, Nosanchuk JD, Zancope-Oliveira RM (2006) Diagnosis of histoplasmosis. Braz J Microbiol 37:1-13.

Guimaraes AJ, Pizzini CV, De Abreu-Almeida M et al. (2010b) Evaluation of an enzyme-linked immunosorbent assay using purified, deglycosylated histoplasmin for different clinical manifestations of histoplasmosis. Microbiol Res (Pavia) 2:1.

Hassan GS, Mukherjee S, Nagajyothi F et al. (2006) Trypanosoma cruzi infection induces proliferation of vascular smooth muscle cells. Infect Immun 74:152-159.

Iglesias R, Locovei S, Roque A et al. (2008) P2X7 receptorPannexin1 complex: pharmacology and signaling. Am J Physiol Cell Physiol 295:C752-760.

Jasmin, Jelicks LA, Koba W et al. (2012) Mesenchymal bone marrow cell therapy in a mouse model of chagas disease. Where do the cells go? PLoS Negl Trop Dis 6:e1971.

Jasmin, Spray DC, Campos de Carvalho AC et al. (2010) Chemical induction of cardiac differentiation in p19 embryonal carcinoma stem cells. Stem Cells Dev 19:403-412.

Jasmin, Torres AL, Jelicks LA et al. (2012b) Labeling stem cells with superparamagnetic iron oxide nanoparticles: analysis of the labeling efficacy by microscopy and magnetic resonance imaging. Methods Mol Biol 906:239-252.

Jasmin, Torres AL, Nunes HM et al. (2011) Optimized labeling of bone marrow mesenchymal cells with superparamagnetic iron oxide nanoparticles and in vivo visualization by magnetic resonance imaging. J Nanobiotechnology 9:4.

Lachtermacher S, Esporcatte BL, Fortes FS et al. (2012) Functional and transcriptomic recovery of infarcted mouse myocardium treated with bone marrow mononuclear cells. Stem Cell Rev 8:251-261.

Lopes LC, Guimaraes AJ, de Cerqueira MD et al. (2010) A Histoplasma capsulatum-specific IgG1 isotype monoclonal antibody, H1C, to a 70-kilodalton cell surface protein is not protective in murine histoplasmosis. Clin Vaccine Immunol 17:1155-1158.

Lopes LC, Rollin-Pinheiro R, Guimaraes A et al. (2010b) Monoclonal antibodies against peptidorhamnomannans of Scedosporium apiospermum enhance the pathogenicity of the fungus. PLoS Negl Trop Dis 4:e853.

Malvestio LM, Celes MR, Milanezi C et al. (2014) Role of dystrophin in acute Trypanosoma cruzi infection. Microbes Infect 16:768-777.

Medina FA, Cohen AW, de Almeida CJ et al. (2007) Immune dysfunction in caveolin-1 null mice following infection with Trypanosoma cruzi (Tulahuen strain). Microbes Infect 9:325-333.

Medina FA, de Almeida CJ, Dew E et al. (2006) Caveolin1-deficient mice show defects in innate immunity and inflammatory immune response during Salmonella enterica serovar Typhimurium infection. Infect Immun 74:66656674.

Nagajyothi F, Desruisseaux M, Bouzahzah B et al. (2006) Cyclin and caveolin expression in an acute model of murine Chagasic myocarditis. Cell Cycle 5:107-112.

Nagajyothi F, Desruisseaux MS, Thiruvur N et al. (2008) Trypanosoma cruzi infection of cultured adipocytes results in an 
inflammatory phenotype. Obesity (Silver Spring) 16:19921997.

Nardelli SC, Che FY, Silmon-de-Monerri NC et al. (2013) The histone code of Toxoplasma gondii comprises conserved and unique posttranslational modifications. MBio 4:e0922.

Nemeth T, Toth A, Hamari Z et al. (2014) Transcriptome profile of the murine macrophage cell response to Candida parapsilosis. Fungal Genet Biol 65:48-56.

Nguyen LN, Cesar GV, Le GT et al. (2012) Inhibition of Candida parapsilosis fatty acid synthase (Fas2) induces mitochondrial cell death in serum. PLoS Pathog 8:e1002879.

Nguyen LN, Lopes LC, Cordero RJ et al. (2011) Sodium butyrate inhibits pathogenic yeast growth and enhances the functions of macrophages. J Antimicrob Chemother 66:2573-2580.

Nosanchuk JD, Nimrichter L, Casadevall A et al. (2008) A role for vesicular transport of macromolecules across cell walls in fungal pathogenesis. Commun Integr Biol 1:37-39.

Nosanchuk JD, Zancope-Oliveira RM, Hamilton AJ et al. (2012) Antibody therapy for histoplasmosis. Front Microbiol 3:21.

Oliveira DL, Freire-de-Lima CG, Nosanchuk JD et al. (2010) Extracellular vesicles from Cryptococcus neoformans modulate macrophage functions. Infect Immun 78:1601-1609.

Oliveira DL, Nakayasu ES, Joffe LS et al. (2010b) Biogenesis of extracellular vesicles in yeast: Many questions with few answers. Commun Integr Biol 3:533-535.

Oliveira DL, Nakayasu ES, Joffe LS et al. (2010c) Characterization of yeast extracellular vesicles: evidence for the participation of different pathways of cellular traffic in vesicle biogenesis. PLoS One 5:e11113.

Oliveira MM, Almeida-Paes R, Gutierrez-Galhardo MC et al. (2014) Molecular identification of the Sporothrix schenckii complex. Rev Iberoam Micol 31:2-6.

Peerzada H, Gandhi JA, Guimaraes AJ et al. (2013) Methamphetamine administration modifies leukocyte proliferation and cytokine production in murine tissues. Immunobiology 218:1063-1068.

Prado CM, Celes MR, Malvestio LM et al. (2012) Early dystrophin disruption in the pathogenesis of experimental chronic Chagas cardiomyopathy. Microbes Infect 14:59-68.

Prado M, Silva MB, Laurenti R et al. (2009) Mortality due to systemic mycoses as a primary cause of death or in association with AIDS in Brazil: a review from 1996 to 2006. Mem Inst Oswaldo Cruz 104:513-521.

Revskaya E, Jongco AM, Sellers RS et al. (2009) Radioimmunotherapy of experimental human metastatic melanoma with melanin-binding antibodies and in combination with dacarbazine. Clin Cancer Res 15:2373-2379.

Rodrigues AM, de Melo-Teixeira M, de Hoog GS et al. (2013) Phylogenetic analysis reveals a high prevalence of
Sporothrix brasiliensis in feline sporotrichosis outbreaks. PLoS Negl Trop Dis 7:e2281.

Rodrigues ML, Nakayasu ES, Oliveira DL et al. (2008) Extracellular vesicles produced by Cryptococcus neoformans contain protein components associated with virulence. Eukaryot Cell 7:58-67.

Rodrigues ML, Nimrichter L, Oliveira DL et al. (2007) Vesicular polysaccharide export in Cryptococcus neoformans is a eukaryotic solution to the problem of fungal trans-cell wall transport. Eukaryot Cell 6:48-59.

Rodrigues ML, Nimrichter L, Oliveira DL et al. (2008b) Vesicular Trans-Cell Wall Transport in Fungi: A Mechanism for the Delivery of Virulence-Associated Macromolecules? Lipid Insights 2:27-40.

Rodrigues ML, Nosanchuk JD, Schrank A et al. (2011) Vesicular transport systems in fungi. Future Microbiol 6:1371-1381.

Rodrigues ML, Shi L, Barreto-Bergter E et al. (2007) Monoclonal antibody to fungal glucosylceramide protects mice against lethal Cryptococcus neoformans infection. Clin Vaccine Immunol 14:1372-1376.

Rossi MA, Tanowitz HB, Malvestio LM et al. (2010) Coronary microvascular disease in chronic Chagas cardiomyopathy including an overview on history, pathology, and other proposed pathogenic mechanisms. PLoS Negl Trop Dis 4:e674.

Shi L, Albuquerque PC, Lazar-Molnar E et al. (2008) A monoclonal antibody to Histoplasma capsulatum alters the intracellular fate of the fungus in murine macrophages. Eukaryot Cell 7:1109-1117.

Sifuentes-Osornio J, Corzo-Leon DE, Ponce-de-Leon LA (2012) Epidemiology of Invasive Fungal Infections in Latin America. Curr Fungal Infect Rep 6:23-34.

Silva-Souza HA, de Lira MN, Patel NK et al. (2014) Inhibitors of the 5-lipoxygenase pathway activate pannexin 1 channels in macrophages via the thromboxane receptor. Am J Physiol Cell Physiol 307:C571-579.

Soares MB, de Lima RS, Rocha LL et al. (2010) Gene expression changes associated with myocarditis and fibrosis in hearts of mice with chronic chagasic cardiomyopathy. J Infect Dis 202:416-426.

Soares MB, Lima RS, Souza BS et al. (2011) Reversion of gene expression alterations in hearts of mice with chronic chagasic cardiomyopathy after transplantation of bone marrow cells. Cell Cycle 10:1448-1455.

Thomaz L, Garcia-Rodas R, Guimaraes AJ et al. (2013) Galleria mellonella as a model host to study Paracoccidioides lutzii and Histoplasma capsulatum. Virulence 4: 139-146.

Associate Editor: Carlos Pelleschi Taborda

All the content of the journal, except where otherwise noted, is licensed under a Creative Commons License CC BY-NC. 